\title{
Effect of anaerobic bovine colostrum fermentation on bacteria growth inhibition
}

\section{Efeito da fermentação anaeróbica do colostro bovino na inibição do crescimento de bactérias}

\author{
Mara Helena Saalfeld ${ }^{\mathrm{I}}$ Daniela Isabel Brayer Pereira ${ }^{\mathrm{II}^{*}}$ Júlia de Souza Silveira Valente $^{\mathrm{II}}$ \\ Jéssica Lopes Borchardt ${ }^{\text {II }}$ Christiano Fanck Weissheimer ${ }^{\text {III }}$ \\ Márcia Arocha Gularte ${ }^{\text {II }}$ Fábio Pereira Leivas Leite ${ }^{\text {II }}$
}

\section{ABSTRACT}

Efficient handling programs that provide high quality colostrum in adequate amounts to dairy farm calves are needed to assure their health and survival. Replacers (or milk substitutes) often become necessary when colostrum presents inadequate quality, or in order to break the cycle of infectious disease transmission. In this study we aimed to assess the effect of anaerobic fermentation processing (colostrum silage) on bacterial that represent interest to animal health. Colostrum samples were inoculated with cultures of Brucella abortus, Escherichia coli, Leptospira interrogans serovar Copenhageni, Mycobacterium bovis, Salmonella Enteritidis, Salmonella Typhimurium, Staphylococcus aureus, and Bacillus cereus and then subjected to anaerobic fermentation. On the first day, and every seven days until $30^{\text {th }}$ days after fermentation, the samples were cultured and colony forming units counted. At seven days of fermentation, B. abortus, L. interrogans, and M. bovis were not detected. At $14^{\text {th }}$ days of fermentation, E. coli, S. aureus, S. Enteritidis and S. Typhimurium were no longer detected. However, we were able to detect both lactic acid bacteria and B. cereus until $30^{\text {th }}$ days of fermentation. From this study we suggested that anaerobic fermentation processing can inhibit important bacteria that cause economical losses for the cattle industry. The observations suggested that colostrum silage is a promising form to conserve bovine colostrum.

Key words: colostrum silage, lactic acid bacteria, calves, milk substitutes.

\section{RESUMO}

Eficientes programas de manejo que permitem o fornecimento de colostro de alta qualidade e em quantidades adequadas para bezerros são necessários para garantir a sua saúde e sobrevivência. Substitutos do leite tornam- se frequentemente necessários quando o colostro apresenta qualidade inadequada ou a fim de quebrar o ciclo de transmissão de doenças infecciosas. Este estudo teve como objetivo avaliar o efeito da fermentação anaeróbica do colostro bovino (silagem de colostro) sobre bactérias de interesse para a saúde animal. Alíquotas de colostro foram inoculadas com culturas de Brucella abortus, Escherichia coli, Leptospira interrogans serovar Copenhageni, Mycobacterium bovis, Salmonella Enteritidis, Salmonella Typhimurium, Staphylococcus aureus e Bacillus cereus e submetidas ao processo de fermentação anaeróbia. No primeiro dia e a cada sete dias até o $30^{\circ}$ dia de fermentação, as alíquotas foram cultivadas e analisadas pela contagem de unidades formadoras de colonias. Aos sete dias de fermentação, unidades formadoras de colônias de B. abortus, $\boldsymbol{L}$. interrogans e M. bovis não foram detectadas e unidades formadoras de colonia de $\boldsymbol{E}$. coli, $\boldsymbol{S}$. aureus, $\boldsymbol{S}$. Enteritidis e $\boldsymbol{S}$. Typhimurium não foram observadas no $14^{\circ}$ dia de fermentação. No entanto, B. cereus e bactérias ácido lácticas foram detectadas até o $30^{\circ}$ dia de fermentação. Este estudo sugere que o processo de fermentação anaeróbia do colostro bovino proporciona efeitos inibitórios sobre as bactérias avaliadas, constituindo-se num promissor método de conservação do colostro bovino.

Palavras-chave: silagem de colostro, bactérias lácticas, bezerros, substitutos do leite.

\section{INTRODUCTION}

Colostrum, the first milk produced by the cow after birth, is rich in nutrients, immunoglobulin, minerals, vitamins and bioactive substances (GODDEN, 2009; KURALKAR \& KURALKAR,

\footnotetext{
IEmater/ASCAR, Pelotas, RS, Brasil. RS, Brasil. E-mail: danielabrayer@gmail.com. "Corresponding author.

IIIEmbrapa Clima Temperado, Pelotas, RS, Brasil.

IDDepartamento de Microbiologia e Parasitologia, Universidade Federal de Pelotas (UFPel), Campus Capão do Leão, 96100-160, Pelotas, 
2010). Lack of hygiene in preparing both the cow and milking equipment, excessive time between milking and suckling, mastitis, all can predispose colostrum contamination by microorganisms (STEWART et al., 2005). Bacteria such as Mycoplasma spp., Mycobacterium spp., Campylobacter spp., Salmonella spp., Listeria monocytogenes, and Escherichia coli, may be present in colostrum due to contamination of the mammary gland, post-milking contamination, or bacterial proliferation through improperly stored colostrum (STABEL et al., 2004).

Staphylococcus aureus, viral bovine diarrhea, and viral bovine leukemia have been added to this list (MCGUIRK \& COLLINS, 2004). However, it is important to note that cows with infectious diseases and/or zoonosis must not be placed on the milking line in order to prevent the transmission of pathogens to humans and animals (BRASIL, 2011).

To ensure administration of contaminant free milking, researchers have recommended the use of commercial substitutes for colostrum (GODDEN et al., 2012; PRIESTLEY et al., 2013).

Healthy cows produce colostrum in amounts above the intake capacity of the calf (39 to $52 \mathrm{~kg}$ ) during the first four days postpartum (FOLEY \& OTTERBY, 1978). Storing surplus colostrum by freezing (RAMÍREZSANTANA et al., 2012), aerobic acidification (FOLEY \& OTTERBY, 1978), use of organic additives (GARCIA et al., 1981), or by anaerobic fermentation (SAALFELD et al., 2013) allows surplus colostrum to be employed in feeding more animals. Anaerobic fermentation (colostrum silage) preserves the nutritional constituents, and ensures the transfer of antibodies to calves (SAALFELD et al., 2013, 2014). Our group demonstrated that environmental microbial contamination of natural colostrum can be eliminated with 21 days of anaerobic fermentation, remaining only lactic acid bacteria (LAB) as viable (SAALFELD et al., 2013).

Considering that knowledge of microbiological parameters is a key to making use of anaerobically fermented colostrum as food to rear calves, the present study was elaborated to evaluate the inhibitory effects of anaerobic colostrum fermentation (colostrum silage) on bacteria of importance to animal health.

\section{MATERIALS AND METHODS}

Colostrum was obtained by mechanical milking of two Holstein cows from the Farmers' Training Center of EMATER - CETAC in Canguçu
RS; complying with the hygiene rules laid down in Instruction 62 of the Ministry of Agriculture and Livestock (BRASIL, 2011). The colostrums milked on the second day postpartum, was transported (refrigerated, $4-6^{\circ} \mathrm{C}$ ) to the microbiology laboratory at the Universidade Federal de Pelotas (UFPel) and divided into eight aliquots of $1,200 \mathrm{~mL}$. Each of these colostrum aliquots was inoculated with the following bacteria: Mycobacterium bovis BCG Pasteur $\left(5 \times 10^{6} \mathrm{CFU} \mathrm{mL}^{-1}\right)$, Brucella abortus vaccine strain B19 $\left(4 \times 10^{9} \mathrm{CFU} \mathrm{mL}^{-1}\right)$, Leptospira interrogans serovar Copenhageni $\left(1 \times 10^{7} \mathrm{CFU} / \mathrm{mL}\right)$, Staphylococcus aureus ATCC $25923\left(5 \times 10^{9} \mathrm{CFU} \mathrm{mL}^{-1}\right)$ Escherichia coli (O141; K88ab; H4) (6x107 CFU mL $\left.\mathrm{mL}^{-1}\right)$, Salmonella Enteritidis ATCC $13076\left(5 \times 10^{10} \mathrm{CFU}\right.$ $\left.\mathrm{mL}^{-1}\right)$, Salmonella Typhimurium ATCC 4028 $\left(6 \times 10^{10} \mathrm{CFU} \mathrm{mL} \mathrm{mL}^{-1}\right)$ and Bacillus cereus ATCC 14579 $\left(6 \times 10^{7} \mathrm{CFU} \mathrm{mL} \mathrm{m}^{-1}\right)$. The inoculums criteria were based in the highest count found in contaminated milk samples by the diagnostic laboratory of School of Veterinary at the Universidade Federal de Pelotas. After bacterial inoculations, each of the eight aliquots was fractionated into five polyethylene terephthalate (PET) $226 \mathrm{~mL}$ bottles, which were completely filled, closed and stored for anaerobic fermentation of the colostrum as previously described by SAALFELD et al. (2013). In addition, five aliquots were stored without bacterial inoculation, constituting the negative control of the experiment. All bacterial cultures were kindly provided by the Bacteriology Laboratory of the Technological Development Center (CDTec/UFPel). The counting of colony forming units (CFU mL-1) for each bacterium was done by serial dilution (base 10 dilution to $\left.10^{-10}\right)$, in duplicate, immediately after the initial inoculation, and upon each seventh day of fermentation, until 30 days of storage. A $1 \mathrm{~mL}$ aliquot of each dilution was seeded by surface spreading with a Drigalski spatula. BHI agar (Brain Heart Infusion, Difco Il, USA) for B. cereus; Chapmann agar (Difco Il, USA) for S. aureus; MacConkey agar (Difco Il, USA) for $\boldsymbol{E}$. coli; BHI agar and MacConkey agar for $\boldsymbol{S}$. Enteritidis and $\boldsymbol{S}$. Typhimurium were used, with incubations at $37^{\circ} \mathrm{C}$ for 24 hours. For M. bovis (BCG) Middlebrook 7H10 culture medium (Difco, USA), was used with incubation at 35 to $37^{\circ} \mathrm{C}$ for 21 days. For $L$. interrogans the medium employed was Ellinghausen-McCullough-Johnson-Harris (EMJH) supplemented with 10\% EMJH (Difco, USA), and incubation at $30^{\circ} \mathrm{C}$ for seven days. For B. abortus it was used Thayer-Martin agar, and sheep blood agar (Difco, USA), incubated at $37^{\circ} \mathrm{C}$ for 10 days. The control sample (without inoculation) was stroked on sheep blood agar (8\%) (Difco, USA) and incubated at 
$37^{\circ} \mathrm{C}$ for 24 hours, and on MRS agar (Man, Rogosa, and Sharpe; Biobras) incubated in microaerophilic environments at $37^{\circ} \mathrm{C}$ for 48 hours to count the LAB. Colony forming unit counting was performed by a manual colony counter (Phoenix-Luferco) using plates having from 30 to 300 colonies. The LAB were submitted to Gram staining, catalase, maltose, VP (Voges-Proskauer), and nitrate tests for genera identification (KONEMAN et al., 2001; BARROS et al., 2009).

A Mann-Whitney test was used to compare the means of the count results. The differences were considered significant at $\mathrm{P}<0.05$.

\section{RESULTS}

Table 1 shows the CFU/mL results from the bacteria inoculated into the anaerobically fermented colostrum. After seven days of colostrum fermentation B. abortus, L. interrogans, and $M$. bovis were not detected. After 14 days of fermentation the same was evidenced for $\boldsymbol{E}$. coli, $\boldsymbol{S}$. aureus, $\boldsymbol{S}$. Enteritidis and $\boldsymbol{S}$. Typhimurium. At the end of the evaluation period (30 days) only the fermented colostrum inoculated with $\boldsymbol{B}$. cereus presented growth. In the control aliquots, after 14 days of fermentation, only LAB were present. An increase in $\mathrm{LAB}$ counts after seven days evaluation $\left(10^{9} \mathrm{CFU} \mathrm{mL} \mathrm{m}^{-1}\right)$ was observed; which then declined at $14^{\text {th }}$ days (to $10^{7} \mathrm{CFU} \mathrm{mL} \mathrm{mL}^{-1}$ ) of fermentation. This same count remained stable until day 30 (Table 1). Morphological and biochemical analyses revealed the presence of gram-positive rods or coco bacilli, singly or in chains; the catalase and nitrate tests were negative; and the maltose and VP tests gave varied results. These features allowed us to classify the isolated LAB as probably of the Lactobacillus genus.

\section{DISCUSSION}

Colostrum is the main food source for newborn calves. However, microbial contamination can cause diseases and interfere with passive absorption of antibodies (GODDEN, 2009). A previous study by SAALFELD et al. (2013) demonstrated that anaerobic colostrum fermentation (silage colostrum) methods kept the nutritional properties necessary for calves after 21 days of fermentation, as well as inhibited the growth of Staphylococcus spp., Enterobacteriaceae, yeast, and filamentous fungi which had been initially present in colostrum. The present study showed that after seven days of colostrum fermentation, growth of B. abortus, L. interrogans, and M. bovis were inhibited. Additionally, S. aureus, E. coli,
S. Enteritidis, and S. Typhimurium showed no growth after 14 days of fermentation. It is believed that microbial growth inhibition might be caused by the low $\mathrm{pH}$ of the fermented colostrum, which on average, has values of 4.0 to 4.3 (SAALFELD et al., 2013). Previous studies by PORTAELS \& PALTYN (1982) showed that the optimum $\mathrm{pH}$ for $\boldsymbol{M}$. bovis growth ranges from 5.8 to 6.5 ; for $\boldsymbol{B}$. abortus 6.6 to 7.4 (PAULIN, 2003), and for Leptospira spp. 7.2 to 7.8 (AVILA et al., 1998). Additionally, it has been suggested that antimicrobial effects may be associated with antimicrobial substances, including bacteriocins, lactoferrin, transferrin, cytokines, and immunoglobulins (SUGIHARTO, 2015) present in the colostrum and which probably survive fermentation. Although, SAALFELD et al. (2014) demonstrated that antibodies remain preserved after the fermentation process, further studies are needed to evaluate the role of antimicrobial substances in fermented colostrum. In addition, in this study, was not our purpose to evaluate the mechanism(s) that may be involved in the growth inhibition observed.

In the present study, the growth of $\boldsymbol{B}$. cereus displayed an initial decrease in bacterial counts, remaining constant at about $2.7 \times 10^{3} \mathrm{CFU}$ $\mathrm{mL}^{-1}$ until assessment day 30 . It is believed that the behavior of this bacteria may be associated with its sporulation ability (KONEMAN et al., 2001), which makes it resistant to physical and chemical factors such as wide $\mathrm{pH}$ range (4.0 to 9.3) (STAACK, 2008). It is likely that the initial count decrease is due to the presence of vegetative cells at the start of the fermentation process. Nonetheless, the persistence of $\boldsymbol{B}$. cereus after the fermentation period must be considered and assessed. Although most cultures of B. cereus are classified as saprobes (PERES-NETO \& ZAPPA, 2011), and characterized as probiotics (TURNES, 1999), some strains may be associated with the occurrence of food-borne disease outbreaks in humans (DHAMA et al., 2013), while others may be associated with cases of mastitis (either subclinical or clinical of environmental origin) in cattle (PERESNETO \& ZAPPA, 2011).

A previous study reported that the decreasing $\mathrm{pH}$ of the colostrum at seven days of fermentation was accompanied by an increase in CFU $\mathrm{mL}^{-1}$ of LAB. These bacteria are able to split lactose into lactic acid, which renders the medium acidic (SAALFELD et al., 2013). In the present study, during the evaluation period, the LAB count stabilized at around $10^{7} \mathrm{CFU} \mathrm{mL}^{-1}$, which was similar to that reported by SAALFELD et al. (2013), who evaluated samples of fermented 
Table 1 - Bacterial count (mean CFU, $\pm \mathrm{SE}$ ) in anaerobic fermented bovine colostrum.

\begin{tabular}{|c|c|c|c|c|c|}
\hline \multirow{2}{*}{ Microorganism } & \multirow{2}{*}{ Day 0} & \multicolumn{4}{|c|}{ 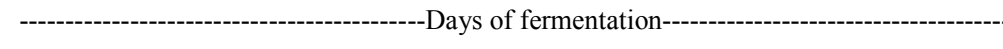 } \\
\hline & & Day 7 & Day 14 & Day 21 & Day 30 \\
\hline Lactic acid bacteria (BAL) & $2,5 \times 10^{7 \mathrm{a}}$ & $6,0 \times 10^{9} \pm 0.05^{b}$ & $5,7 \times 10^{7} \pm 0.07^{\mathrm{a}}$ & $2,8 \times 10^{7} \pm 0.04^{\mathrm{a}}$ & $2,5 \times 10^{7} \pm 0.05^{\mathrm{a}}$ \\
\hline Brucella abortus & $40 \times 10^{7}$ & ND & ND & ND & ND \\
\hline Bacillus cereus & $6 \times 10^{7 \mathrm{a}}$ & $3,5 \times 10^{3} \pm 0.04^{\mathrm{b}}$ & $2,7 \times 10^{3} \pm 0.05^{\mathrm{b}}$ & $2,7 \times 10^{3} \pm 0.06^{\mathrm{b}}$ & $2,7 \times 10^{3} \pm 0.05^{b}$ \\
\hline Escherichia coli & $6 \times 10^{7 a}$ & $3,0 \times 10^{3} \pm 0.05^{\mathrm{b}}$ & ND & ND & ND \\
\hline Leptospira interrogans & $1 \times 10^{7}$ & ND & ND & ND & ND \\
\hline Mycobacterium bovis & $0.5 \times 10^{7}$ & ND & ND & ND & ND \\
\hline Salmonella Enteritidis & $100 \times 10^{7 a}$ & $4,0 \times 10^{6} \pm 0.06^{\mathrm{b}}$ & ND & ND & ND \\
\hline Salmonella Thyphimurium & $100 \times 10^{7 a}$ & $5,0 \times 10^{5} \pm 0.03^{b}$ & ND & ND & ND \\
\hline Staphylococcus aureus & $50 \times 10^{7 a}$ & $3,0 \times 10^{4} \pm 0.05^{\mathrm{b}}$ & ND & ND & ND \\
\hline
\end{tabular}

${ }^{\mathrm{a}-\mathrm{b}}$ Means lacking a common lowercase letter differ $(P<0.05)$, using a Mann-Whitney test; ND: not detected.

colostrum for up to 360 days of storage, showing that $\mathrm{LAB}$ remained viable throughout the studied period. Besides this $\mathrm{pH}$ action, the lactic acid bacteria have the ability to produce antimicrobial compounds called bacteriocins (BURITI \& SAAD, 2007), inhibitory substances, such as hydrogen peroxide, diacetyl, oxygen metabolites, and others (PIARD \& DESMAZEAUD, 1991). Many lactic acid bacteria play an important role in the production of fermented foods by inhibiting the growth of a wide variety of food spoiling organisms (JACK et al., 1995). Studies showed that bacterial genera considered as lactic acid, like Lactobacillus, Bifidobacterium, Enterococcus, Pediococcus, Lactococcus, Leuconstoc and Streptococcus thermophilus have probiotic potential (HOLZAPFEL et al., 2001; GIRAFFA, 2004). However, microbial characteristics, and probiotic potential were not assessed in this study. Further studies are needed to identify whether fermented colostrum presents LAB with probiotic characteristics. Phenotypic classification of LAB colonies was made according to their physiological, morphological, and biochemical characteristics, assuming that, among other features, the lactic acid bacteria are gram-positive microorganisms, catalase negative, non-sporulating, and nitrate negative (BARROS et al., 2009).

Although colostrum fermentation process prevents growth of non-sporulating pathogenic bacteria, it still remains essential that producers pay attention to milking hygiene and herd sanitation to minimize bacterial contamination during harvesting and storage of colostrum.

\section{CONCLUSION}

The anaerobic colostrum fermentation process was able to inhibit the growth bacteria including $B$. abortus, $E$. coli, $L$. interrogans, $M$. bovis, S. Enteritidis, $S$. Typhimurium, and $S$. aureus. These represent major bacteria of concern to the dairy industry, thus it is possible to suggest and recommend anaerobic colostrum fermentation as an alternative to provide colostrum to calves. The lactic acid bacteria which remained throughout the fermentation process likely kept retained their probiotic activity, adding the benefits of this technique.

\section{ACKNOWLEDGMENTS}

The authors wish to thank the Brazilian Institutes: and Coordenação de Aperfeiçoamento de Pessoal de Nível Superior (CAPES) for providing scholarship and research grants to the authors, as well as, the Graduate Program in Biotechnology/ Universidade Federal de Pelotas (UFPel).

\section{REFERENCES}

AVILA, M.O. et al. Leptospiral agglutinins in dogs in the influence area of the center for control of zoonosis, Pelotas city, RS, Brazil, 1995. Cienc Rural, v.28, p.107-110, 1998. Available from: < http://www.scielo.br/pdf/cr/v28n1/a18v28n1. pdf $>$. Accessed: May 30, 2015.

BARROS, M.R. et al. Comparação entre método bioquímico e reação em cadeia de polimerase para identificação de Lactobacillus spp. isolados de aves. Arq Bras Med Vet Zootec, v.61, p.319-325, 2009. Available from: <http://www.scielo.br/pdf/abmvz/v61n2/ a06v61n2.pdf $>$. Accessed: Apr. 23, 2015.

BRASIL - MINISTÉRIO DA AGRICULTURA, PECUÁRIA E ABASTECIMENTO GABINETE DO MINISTRO. Instrução 
normativa n. 62, de 29 de dezembro de 2011. Diário Oficial da União, n. 251, sec.1, 31 de dezembro de 2011. Available from: <http://sistemasweb.agricultura.gov.br/sislegis/ action/detalhaAto.do? method $=$ consultarLegislacaoFederal $>$. Accessed: Apr. 20, 2015.

BURITI, F.C.A.; SAAD, S.M.I. Bactérias do grupo Lactobacillus casei: caracterização,viabilidade como probióticos em alimentos e sua importância para a saúde humana. ALAN [online], v.57, p.373-380, 2007. Available from: <http://www.scielo.org.ve/pdf/ alan/v57n4/art10.pdf >. Accessed: Mar. 02, 2015.

DHAMA. K. et al. Food-borne pathogens of animal origindiagnosis, prevention, control and their zoonotic significance: a review. Pak J Biol Sci, v.15, p.1076-1085, 2013. Available from: $<$ http://www.ncbi.nlm.nih.gov/pubmed/24506006> $\quad$ Accessed: Mar. 02, 2015. doi: PMID: 24506006.

FOLEY, J.A.; OTTERBY, D.E. Availability, storage, treatment, composition, and feeding value of surplus colostrums: a review. J Dairy Sci, v.61, p.1033-1060, 1978. Available from: <http://www.sciencedirect.com/science/ article/pii/S0022030278836868)>. Accessed: May 12, 2015. doi: $10.3168 /$ jds.S0022-0302 (78) 83686-8.

GARCIA, F. et al. Preservacion de calostro, I. Efecto de aditivos organicos. Ciência e Investigação Agrária, v.8, p.6980, 1981. Available from: <http://biblat.unam.mx/es/buscar/ preservacion-de-calostro-i-efecto-de-aditivos-organicos>. Accessed: Feb. 20, 2015.

GIRAFFA, G. Functionality of enterococci in dairy products. Int J Food Microbiol, v.88, p.215-222, 2003. Available from: <http://www.sciencedirect.com/science/ article/pii/S0168160503001831>. Accessed: Oct. 13, 2015. doi: 10.1016/S0168-1605(03)00183-1.

GODDEN, S. Microbial risks associated with feeding colostrum to calves. Annu Mtg Southwest Nutrition and Management Conference, 2009, p.44-52. Available from: $<$ http://www.dairyweb.ca/Resources/SWNMC2009/Godden. pdf $>$. Accessed: Apr. 14, 2015.

GODDEN, S.M. et al. Heat-treated colostrum and reduced morbidity in preweaned dairy calves: results of a randomized trial and examination of mechanisms of effectiveness. J Dairy Sci, v.95, p.4029-4040, 2012. Available from: <http://www.ncbi. nlm.nih.gov/pubmed/22720957>. Accessed: Feb. 10, 2015. doi: 10.3168/jds.2011-5275.

HOLZAPFEL, W.H. et al. Taxonomy and important features of probiotic microorganisms in food and nutrition. Am J Clin Nutr, v.73, Suppl.2, p.365S-373S, 2001. Available from: <http://www. ncbi.nlm.nih.gov/pubmed/11157343>. Accessed: Apr. 12, 2015.

JACK, R.W. et al. Bacteriocins of Gram-positive bacteria. Microbiol Rev, v.59, p.171-200, 1995. Available from: <http:// www.ncbi.nlm.nih.gov/pmc/articles/PMC239359/pdf/590171. pdf $>$. Accessed: Oct. 23, 2015.

KONEMAN, E.W. et al. Bacilos aeróbios Gram-positivos. In: . Diagnóstico microbiológico - Texto e atlas colorido. 5.ed. Rio de Janeiro: Medsi, 2001. Cap.13, p.661-718.

KURALKAR, P.; KURALKAR, S.V. Nutritional and immunological importance of colostrum for the new born. Vet
World, v.3, p.46-47, 2010. Available from: <http://www. ejmanager.com/mnstemps/2/2-1296810600.pdf?t=1366750634>. Accessed: Sept. 25, 2015.

MCGUIRK, S.; COLLINS, M. Managing the production, storage and delivery of colostrum. Vet Clin North Am: Food Anim Pract, v.20, p.593-603, 2004. Available from: <http://www.sciencedirect. com/science/article/pii/S0749072004000544>. Accessed: Mar. 20, 2015. doi: 10.1016/j.cvfa.2004.06.005.

PAULIN, L.M. Artigo de revisão - Brucelose. Arq Inst Biol, v.70, p.239-249, 2003. Available from: <http:// www.biologico.sp.gov.br/docs/arq/V70_2/paulin.pdf $>$. Accessed: Jun. 12, 2015.

PERES-NETO, F.; ZAPPA, V. Mastite em vacas leiteiras - Revisão de literatura. Rev Cient Eletr Med Veter, v.16, p.1-28, 2011. Available from: <http://faef.revista.inf.br/imagens arquivos/ arquivos_destaque/5birfPwQOBxdHFp_2013-6-26-11-19-44. pdf $>$. Accessed: July 25, 2015.

PIARD, J.C.; DESMAZEAUD, M. Inhibiting factors produced by lactic acid bacteria-1. Oxygen metabolites and products from catabolism. Le Lait, v.71, p.525-541, 1991. Available from: $<$ https://hal.archives-ouvertes.fr/hal-00929265/document $>$. Accessed: July 28, 2015.

PORTAELS, F.; PALTYN, S.R. Growth of Mycobacteria in relation to the $\mathrm{pH}$ of the medium. Ann Microbiol (Paris), v.133, p.213-221, 1982. Available from: <http://www.ncbi.nlm.nih.gov/ pubmed/7149523>. Accessed: Oct. 23, 2015.

PRIESTLEY, D. et al. Effect of feeding maternal colostrum or plasma-derived or colostrum-derived colostrum replacer on passive transfer of immunity, health, and performance of preweaning heifer calves. J Dairy Sci, v.96, p.3247-3256, 2013. Available from: <http://www.sciencedirect.com/science/ article/pii/S0022030213002099>. Accessed: Dec. 01, 2015. doi: $10.3168 /$ jds.2012-6339.

RAMÍREZ-SANTANA, C. et al. Effects of cooling and freezing storage on the stability of bioactive factors in human colostrum. $\mathbf{J}$ Dairy Sci, v.95, p.2319-2325, 2012. Available from: <http://www. ncbi.nlm.nih.gov/pubmed/22541460>. Accessed: Mar. 23, 2015. doi: $10.3168 /$ jds.2011-5066.

SAALFELD, M.H. et al. Anaerobically fermented colostrum: an alternative for feeding calves. Cienc Rural, v.43, p.1636-1641, 2013. Available from: <http://www.scielo.br/ scielo.php? pid $=$ S0103-84782013000900016\&script $=$ sci arttext>. Accessed: Feb. 15, 2015. doi: 10.1590/S010384782013000900016 .

SAALFELD, M.H. et al. Evaluation of the transfer of immunoglobulin from colostrum anaerobic fermentation (colostrum silage) to newborn calves. Anim Sci J, v.85, p.963-967, 2014. Available from: <http://www.ncbi.nlm. nih.gov/pubmed/24990486>. Accessed: Mar. 24, 2015. doi: 10.1111/asj.12229.

STAACK, N. Effects of temperature, $\mathrm{pH}$, and controlled water activity on inactivation of spores of Bacillus cereus in paprika powder by near-IR radiation. J Food Eng, v.89, p.319-324, 2008. Available from: $<\mathrm{http}: / / \mathrm{www}$. sciencedirect.com/science/ article/pii/S0260877408002379>. Accessed: Nov. 03, 2015. doi:10.1016/j.jfoodeng.2008.05.010. 
STABEL, J.R. et al. Destruction of Mycobacterium paratuberculosis, Salmonella spp., and Mycoplasma spp. in raw milk by a commercial on-farm high-temperature, short-time pasteurizer. J Dairy Sci, v.87, p.2177-2183, 2004. Available from: <http://www.ncbi.nlm.nih.gov/ pubmed/15328232>. Accessed: Mar. 02, 2015.

STEWART, S. et al. Preventing bacterial contamination and proliferation during the harvest, storage, and feeding of fresh bovine colostrum. J Dairy Sci, v.88, p.25712578, 2005. Available from: <http://www.ncbi.nlm.nih.gov/ pubmed/15956318>. Accessed: Mar. 02, 2015.
SUGIHARTO, S. Effect of bovine colostrum feeding in comparison with milk replacer and natural feeding on the immune responses and colonization of enterotoxigenic Escherichia coli in the intestinal tissue of piglets. Br J Nutr, v.113, p.923-934, 2015. Available from: $<$ http://www.ncbi.nlm.nih.gov/pubmed/25743486>. Accessed: Nov. 03, 2015. doi: $10.1017 / \mathrm{S} 0007114514003201$.

TURNES, C.G. et al. Properties of the Bacillus cereus strain used in probiotic CenBiot. Rev Microbiol, v.30, p.11-14, 1999. Available from: $\quad<$ http://www.scielo.br/scielo.php?pid=S000137141999000100002\&script $=$ sci arttext $>$. Acessed: Apr. 23, 2015. doi: $10.1590 / \mathrm{S} 0001-37141999000100002$. 